\title{
C-P 結合を有する脂質について
}

\author{
堀 太 郎 \\ 滋賀大学教育学部化学教室（滋賀県大津市石山平津町 179）
}

The Presence of Lipids with a Carbon-Phosphorus Bond

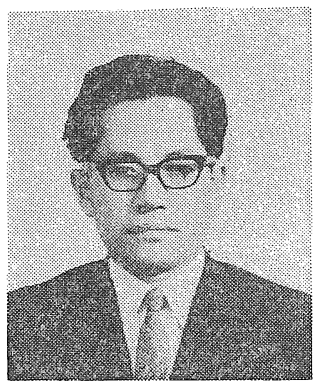

\author{
Tarō HorI \\ Department of Chemistry, Faculty of Liberal Arts and Education \\ University of Shiga (Otsu, Shiga)
}

\section{1 はじ約に}

C-P 結合を有する化合物ときくと，有機リン殺虫剂 を思い出す人が多いと思う。それもそのはずで最近やか ましくいわれている公害問題で水質污濁に係わる環境規 準が国で設けられ (昭和 45 年 4 月 21 日), その規隻項 目に有機リンが加えられたからである。工場や都市下水 路の排水中に $1 \mathrm{ppm}$ の有機リンが含有するとき一定の 規制を受けることになっていて, 一時は殺虫剤として重 宝がられた有機リン化合物も今日では色眼鏡で見られる ようになった。しかし，有機リン殺虫剤がすべて C-P 結合をむっているのではなく, むしろ, 比較的特殊な夕 イプに属していて, サリンのようなアルキルホスホネー トと EPN で代表されるフェニルホスホネートの 2 系列 がそれらである。そして，これらはいずれも，ほかの有 機リン剤と同様, 動物の cholinesterase を阻害するこ とによって激しい毒作用を示す。この阻害機序もしだい に明らかになろうとしているが，P-F (サリン)，P-Oaryl（EPN，いずれも図-1 参照）の開裂によって生ず るホスホネート残基が cholinesterase と化合してリン 化合体となり失活するといわれている。この場合, リン 剂中の C-P 結合部位は切断されることはない1)。<smiles>CP(C)(=O)F</smiles>

サリン

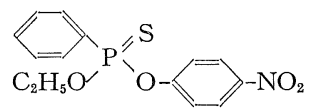

EPN
図-1 C-P 結合を有する代表的な有機リン殺虫刋の構造

本題から話がそれたようであるが，紹介している殺虫 剤の C-P 化合物は合成品である。それに引き換え, こ れから述べようとする C-P 化合物は天然から 10 年ほど 前にわが国の研究者によって発見された物質である2)。 反すう胃に寄生する絨毛虫（rumen ciliate）から単離さ れたのでシリアチン (ciliatine) と命名されたが，一般 には 2-aminoethylphosphonic acid (2-AEP) と呼んで
いる。その後, 生体から数種の類縁化合物が発見される 一方， ${ }^{32} \mathrm{P}$ の取り込みや C-P 結合の開裂の機構，とく に，脂質成分となって下等動物に広く分布していること が明らかにされるに至っている。

1970 年の第 43 回日本生化学会大会では, C-P 化合 物のシンポジウムがもたれた。この機会にわけても， 脂質の面からみた C-P 化合物について述べることは意 味のあることだと考え，編集委員会からの御依頼にこた えた次第である。なお，これまで述べられているシリ

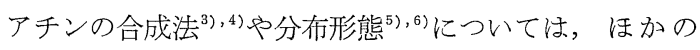
総説を参照されたい。

\section{2 天然に存在する $\mathbf{C}-\mathbf{P}$ 化合物と性質}

前節に述べた 2-AEP のほか, 天然から 6 種の類縁物 が発見されている。表-1 に名称, 構造式, および単離 に用いられた生物名を一括して示した。これら 6 種のう ち，2-AEP の性質が最も深く研究されているが，表-1 の構造式からもわかるように, これは一種のアミノ酸で あると考えることができる。すなわち，電離指数のう ち, $p K_{1} 2.45$ と $p K_{2} 7.0$ は ethylphosphonic acid $\mathrm{HO} \cdot \mathrm{CH}_{2} \cdot \mathrm{CH}_{2} \cdot \mathrm{PO}(\mathrm{OH})_{2}$ の 2.45 と 7.85 のそれぞれ に相当し，また，ホルモル滴定法から得られる 2-AEP の $p K_{3} 10.8$ は $\mathrm{CH}_{3} \cdot \mathrm{CH}_{2} \cdot \mathrm{NH}_{3}{ }^{+}$の $p K_{3} 10.7$ に酷似 する值を示す。この事実から 2-AEP は水溶液中で zwitter ion となることがわかる $\left(\mathrm{NH}_{2} \cdot \mathrm{CH}_{2} \cdot \mathrm{CH}_{2} \cdot \mathrm{PO}\right.$. $\left.(\mathrm{OH})_{2} \rightleftarrows \mathrm{NH}_{3}+\cdot \mathrm{CH}_{2} \cdot \mathrm{CH}_{2} \cdot \mathrm{PO}(\mathrm{OH}) \mathrm{O}^{-}\right)_{\text {。 }}$

$\mathrm{C}-\mathrm{P}$ 化合物のちち，2-AEP，すなわち，シリアチン は遊離の状態でも存在していることは確かである7)(後 述）が，そのほかの類縁物についてはこの点が充分榆討 できていない。しかし，この化合物が生体成分を構成す る重要な物質に染く関係することは事実であろう。

\section{$3 \mathbf{C}-\mathbf{P}$ 結合脂質}

リン酸を含む脂質は一般に複合脂質として取り扱わ 
衣-1 天然に存在するシリアチン (2-AEP) およびその類縁物

\begin{tabular}{|c|c|c|}
\hline 称 & 構 造 & 生 物 \\
\hline $\begin{array}{l}\text { シリアチン } \\
\text { (2-aminoethylphosphonic acid) }\end{array}$ & $\begin{array}{c}\stackrel{\mathrm{O}}{\uparrow} \\
\mathrm{NH}_{2}-\mathrm{CH}_{2}-\mathrm{CH}_{2}-\underset{\mathrm{P}}{\mathrm{p}}-\mathrm{OH} \\
\stackrel{\mathrm{O}}{\mathrm{H}}\end{array}$ & $\begin{array}{l}\text { 反矛う } \\
\text { 繊毛 } \\
\text { 虫 }\end{array}$ \\
\hline $\begin{array}{l}\text { ホスホノアラニン } \\
\text { (2-amino-3-phosphono- } \\
\text { propionic acid) }\end{array}$ & $\begin{array}{cc}\mathrm{O} \\
\mathrm{NH}_{2}-\mathrm{CH}-\mathrm{CH}_{2}-\stackrel{\mathrm{P}}{1}-\mathrm{OH} \\
\mathrm{COOH} \quad \stackrel{\mathrm{O}}{\mathrm{O}}\end{array}$ & 腔 腸 \\
\hline $\begin{array}{l}\text { モノメチルシリアチン } \\
\text { (N-methyl-aminoethyl-. } \\
\text { phosphonic acid) }\end{array}$ & $\begin{array}{c}\stackrel{\mathrm{O}}{\uparrow} \\
\mathrm{CH}_{3}-\mathrm{NH}-\mathrm{CH}_{2}-\mathrm{CH}_{2}-\underset{\mathrm{P}}{\mathrm{I}}-\mathrm{OH} \\
\mathrm{OH}\end{array}$ & $\begin{array}{l}\text { 貝 類 } \\
\text { 䐋 腸 }\end{array}$ \\
\hline $\begin{array}{l}\text { ジメチルシリアチン } \\
\text { (N,N-dimethyl-2-aminoethyl- } \\
\text { phosphonic acid) }\end{array}$ & $\begin{array}{cc} & \mathrm{O} \\
\mathrm{CH}_{3}-\mathrm{N}-\mathrm{CH}_{2}-\mathrm{CH}_{2}-\stackrel{\uparrow}{\mathrm{P}}-\mathrm{OH} \\
1 \mathrm{CH}_{3} & \mathrm{O} \\
& \mathrm{O}\end{array}$ & 腔 腸 \\
\hline $\begin{array}{l}\text { トリメチルシリアチン } \\
\text { (trimethyl-2-phosphonoethyl- } \\
\text { ammonium hydroxide) }\end{array}$ & $\begin{array}{cc} & \mathrm{O} \\
\left(\mathrm{CH}_{3}\right)_{3}-\mathrm{N}-\mathrm{CH}_{2}-\mathrm{CH}_{2}-\stackrel{\uparrow}{\mathrm{P}}-\mathrm{OH} \\
\mathrm{O} \mathrm{O} & \mathrm{OH}\end{array}$ & 腔 腸 \\
\hline $\begin{array}{l}\text { アシルシリアチン } \\
\text { (N-acyl-2-aminoethyl- } \\
\text { phosphonic acid) }\end{array}$ & $\begin{array}{cc} & \mathrm{O} \\
\mathrm{RCO}-\mathrm{N}-\mathrm{CH}_{2}-\mathrm{CH}_{2}-\stackrel{\uparrow}{\mathrm{P}}-\mathrm{OH} \\
\mathrm{H} & \mathrm{O} \\
\mathrm{O} & \mathrm{H}\end{array}$ & 具 類 \\
\hline $\begin{array}{r}\text { アシルメチルシリアチン } \\
(\mathrm{N}, \mathrm{N} \text {-acylmethyl-2-aminoethyl- } \\
\text { phosphonic acid })\end{array}$ & $\begin{array}{cc} & \mathrm{O} \\
\mathrm{RCO}-\mathrm{N}-\mathrm{CH}_{2}-\mathrm{CH}_{2}-\stackrel{\uparrow}{\mathrm{P}}-\mathrm{OH} \\
\mathrm{CH}_{3} & \mathrm{O} \\
\mathrm{H}_{3} & \end{array}$ & 具 類 \\
\hline
\end{tabular}

巻貝のナガタニシ, Heterogen longispira から発見された sphingoethanolamine(ceramide aminoethylphosphate) ${ }^{11), 12)}$ の C-P アナローグであるということができる。

ところで，前者のグリセロ脂質(図-2 (A)) については Dawson や Liang らを含め数 人の学者によって，存在が認められている が，推定の域を出ていないと考光た方が妥当 である。その理由について少し触れてみよ う。

Kittredge ら ${ }^{13)}$ はイソギンチャク，Anthopleura elegentissima のアルコール抽出物 を加水分解し，分解成績体をペーパークロマ トで調べて glyceryl 2-AEP を検出したこと を報じた（1962）。また，Liang ら ら $^{14)}$ 源生 動物, Tetrahymena phriformis 飞 ${ }^{32} \mathrm{P} を$ 取り込ませて C-P 結合脂質の生合成機構を 研究して

$$
\begin{gathered}
\mathrm{CTP}+2-\mathrm{AEP} \rightleftharpoons \mathrm{CMP}-2-\mathrm{AEP}+\mathrm{PP}_{i} \\
\underset{\mid}{d \text { diglyceride }} \\
2-\mathrm{AEP}-\mathrm{glyceride}+\mathrm{CMP} \\
\text { (図-2(A) 参照) }
\end{gathered}
$$

なる経路で進むと報じているが，グリセロ脂 質自体を単離していない（1966）。一方，<smiles>[R]C(=O)OCC(COP(=O)(O)CC[NH3+])C([Y10])CC[NH3+]</smiles>

(A)

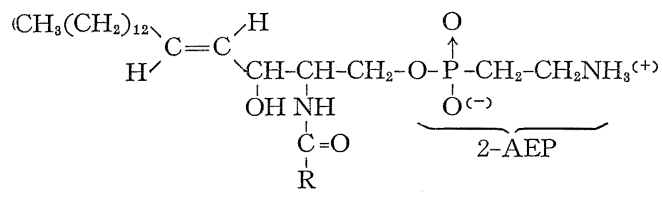

(B)

(A) グリセロ脂質型 diacylglycerol-(2-aminoethyl) phosphonate

（B）スフィンゴ脂質型 erythro-N-acyl-sphingosyl-1(2-aminoethyl)-phosphonate

\section{図-2 C-P 結合脂質}

れ，その二つの基本的な型として，グリセロ脂質とスフ インゴ脂質があることは周知の通りである。そして， C-P 化合物もこれら両型の構成成分となって，天然に 存在すると考えられているようである。

図-2 (A) 性物全般に広く分布する phosphatidylethanolamine $^{9)}$ の C-P アナローグともいうべき脂質 であり，図-2(B) は著者ら ${ }^{10)}$ にり，1965 年，淡水産
Dawson ${ }^{15}$ は反すう胃に寄生する原生動物を多量に培養 （約 $1 \mathrm{~kg}$ ）し，これよりスフィンゴ脂質型（後述）を単 離同定しているが，グリセロ脂質型のものについては加 水分解物索検索しているに止まっている (1967)。その ほか，最近において，Kapoulas ${ }^{16)}$ が TLC 上に Baer の合成品 ${ }^{17)}$ distearoyl L- $\alpha$-glyceryl-(2-aminoethyl) phosphonate と一致するスポットを得ているが，構造決 定までに至っていない (1969)。また，Smith ら ${ }^{18)}$ はテ トラヒメナの緎毛に 2-AEP を成分とする alkoxy acyl 型のグリセロ脂質の存在を推定している (1970)。以上 いずれも単離, 同定にあっては群盲の域に踏みとどまっ ている感がする。

おそらく，天然に存在するのであろらが，微量のゆえ か，こらした研究者の努力にもかかわらす，単離に成功 していないのが実情である。

これに対し，スフィンゴ脂質型の場合は，構造も決定 され，生物界における分布も明らかになった。とくに， 軟体動物の二枚貝や巻貝には全リン脂質量の $7 \sim 20 \%$ が この脂質である。構造は $\operatorname{Simon}^{19)}$ らの過ギ酸酸化法と 著者ら ${ }^{20)}$ の phospholipase C を用いる酵素法の二方面 から調べられ, その結果, 図-2 に示すような ceramide 2-aminoethylphosphonate (CAEP) であることが立 証された。図-3 は酸化法を用いたときの scheme であ る。 


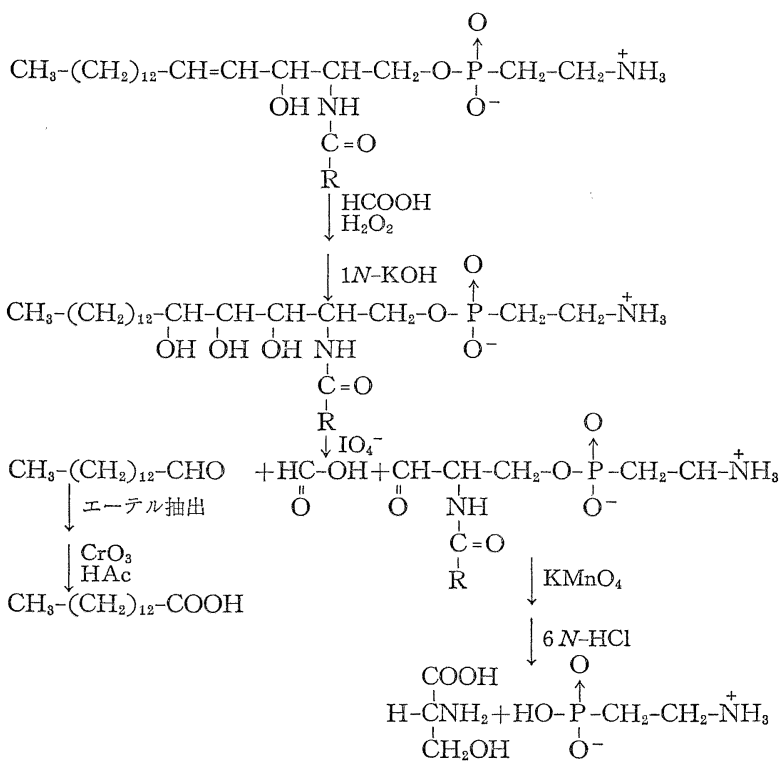

図-3 酸化法による ceramide 2-aminoethylphosphonate の分解
コン虫類

(1)イナゴ Oxya viuna

甲殼 類

(2)アメリカザリガニ

\section{Cambarus clarkii}

(3)エビ Leander paucidens 頭 足 類

(4)タコ Polypus vulgaris

双 款 類

(5)アコヤガイ

(6)セタシジミ

Pinctada martensii

Corbicula sandai (9)

(7)ヌマガイ Anodonta lauta

腹 足 類

8)ベッコウザラ

$$
\text { Cellana eucosmia }{ }^{11}
$$

(9)アワビ Haliotis gurneri (12)

(10イシダタミ Monodonta labio
(1)

(2)

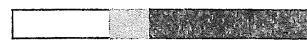

(4)

(5)

(6)

(7)

(8)
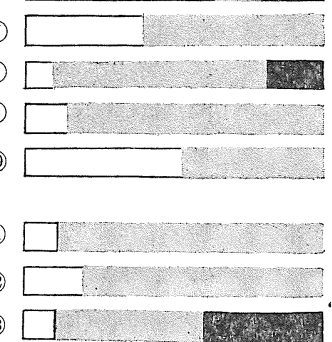
(14)

Batillaria multiformis ${ }^{(14)}$ (12)ナガタニシ (13)カワニナ Heterogen longispira

Semisulcospira bensoni (14) レイシ Purpura bronni (17) (15)テソグニシ

$$
\text { Pugilina ternatana }
$$

環形動物 (16ミミズ

線形動物

(17)カイチュウ

Pheretinra communessima

Ascaris lumbiocodes

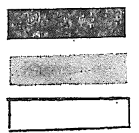
sphingomyelin

$\mathrm{C}-\mathrm{P}$ 結合脂質

その他のリン脂質

図-4 動物界に拈ける CAEP の分布

\section{Ceramide 2-aminoethylphosphonate (CAEP) の分布とその類緑脂質}

$4 \cdot 1$ 分 布

原生動物（テトラヒメナ），腔腸動物（イソギン チャク), 腹足類 (マイマイ, レイシ。タニシ類, サザエ)，二枚貝（シジミ，アコヤガイ），頭足類 (イカ, タコ)，コン虫類（イナゴ）に発見されてい る。分類学上，新口動物からの発見をあまり聞かな いが，最近，Rouser が棘皮動物のウニに存在する ことを報している ${ }^{21}$ 。図一注著者らの研究室で行な った分布調查の結果であるが22,23)，検体の phosphosphingolipid 画分中に抒ける CAEP（後述す る類縁物質も含む）の量比を示している。ここで注 意を引くことは，たとえば，二枚貝のセタシジミ Corbicula sandai やヌマガイ Anodonta lauta, 巻貝のイシダタミ Monodonta labio やアワビ Haliotis-gurneri には，動物に広く分布すると考 えられている sphingomyelin（背椎動物の phosphosphingolipid はほとんどがこの脂質）をまったく含 有していないことである。この事実や図-4の含有比から みて軟体動物では, CAEP が高等動物の sphingomyelin 一一神経組織の働きに深い関倸をもつ——相当する役 目を果たしているのではなかららか。

\subsection{CAEP の類緑脂質}

2-AEP のほか, 天然化存在する C-P 化合物 (表-1) 中，脂質成分となっているものに，モノメチルシリアチ ンがある。林ら ${ }^{24)}$ によりサザエ Turbo cornutas か ら最初発見された。その後, 著者らによって構造が決 定 (ceramide $\mathrm{N}$-methyl-2-aminoethylphosphonate, CMAEP，図-5）され，ほかの貝類たとえば，セタシ ジミ，カワニナ Semisulcospira bensoni, クボガイ Tegula pfeifferi, アワビ Stomatella lyrata にも含有 寸ることが明らかになった ${ }^{25}$ 。しかし，ジ一，トリメ チル化合物（表-1）が脂質の成分となっていることにつ いてはなお，不明である。

一方, CAEP や CMAEP の N-acyl 化物 (図-5) が貝類から発見されている。セタシジミからは両者が,

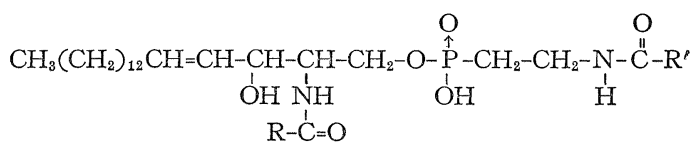

ceramide $\mathrm{N}$-acyl-2-aminoethylphosphonate<smiles>[R]CNC(COP(=O)(O)CCN(C)C([R])=O)C(O)C([R])C(C)CC</smiles>

ceramide N,N-acylmethyl-2-aminoethylphosphonate

図-5 C-P 化合物を含有するスフィンゴ脂質 (N-acyl 体) の構造 


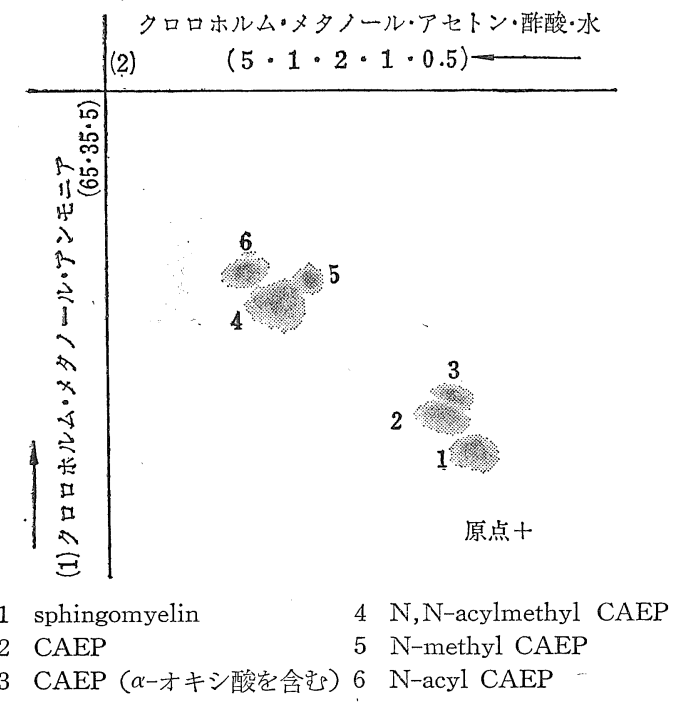

図-6＼cjkstart貝類の CAEP および類縁脂質の薄層クロマトグラム

そして，真珠の母貝であるアコヤガイ Pinctada martensii からは前者が，イシダタミからは後者がそれぞれ 単離された ${ }^{26), 27)}$ 。

これらスフィンゴ脂質の脂肪酸成分は主として, パル ミチン，マーガリン，ステアリンで不飽和酸は含んでい ないが，オキシ酸を含有する脂質は，セラミド部分にこ の酸をもち，TLCによりそのホモローグが区別できる

(図-6)。オキシ酸は $\alpha$-hydroxypalmitic および hydroxymargaric の 2 種が見いだされている ${ }^{28)}$ 。また， 長鎖状塩基成分については, sphingosine と dihydrosphingosine がおもなものであるが， $\mathrm{C}_{16}$-sphingosine, $\mathrm{C}_{16}$-dihydrosphingosine も存在する。セタシジミには sphinga-4,8-dienine も存在する ${ }^{29)}$ 。

\section{3 光学活性}

Baer ら ${ }^{30}$ により，1969 年，CAEP が全合成された。 合成標品 erythro-N-palmitoyl-D-sphingosyl-1- (2aminoethyl) phosphonate $の[\alpha]_{\mathrm{D}}$ が $+25.1^{\circ}$ で, そ の光学的詨掌体の L 型は $-23.6^{\circ}$ である。著者らがセ タシジミから単離したものは $+20^{\circ}(1.1 \%)$ を示すこと 汃ら，天然型のものは D-sphingosine の誘導体である と考えられる。また，その他の類縁脂質（図-5) の比旋 光度もクロロホルムーメタノール溶液で $+12^{\circ} \sim 15^{\circ}$ を与 えるから，やはり，D-sphingosine の誘導体である う。

\section{5 生合成と分解}

\section{$5 \cdot 1$ 生 合 成}

2-AEP (シリアチン) の合成経路は, 無細胞系が不安 定であるため, テトラヒメナ生細胞の ${ }^{14} \mathrm{C}-$ 化合物の取 り込み実験の結果に基づいて推測されている場合が多

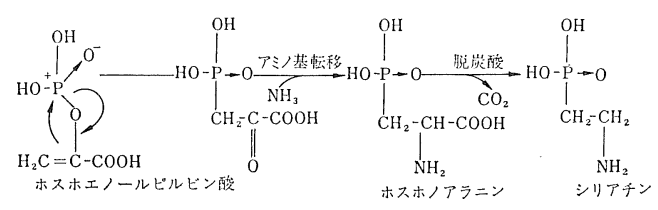

図-7 ホスホエノールピルビン酸の分子内 再配列による 2-AEP の合成経路

い。たとえば Kittredge ${ }^{31)}$ によると，オキザ口酢酸 ホスホノアラニン $\rightarrow 2-\mathrm{AEP}$ と進み，脂質と結合する考 え方であり，Warren ${ }^{322}$ はホスホエノールピルビン酸の 分子内再配列によって C-P 結合 (図-7) が生じ，その 後, アミノ基転移と脱炭酸によって, 遊離の 2-AEP が できると考えるものである。

\section{2 分 解}

C-P 結合はきわめて安定であって, 酸やアルカリに よる長時間の加水分解も受けない。また, シロネズミに 投与しても，尿やフン中にそのままの形 (2-AEP) で排 泄される。しかし，ウシやヒツジの胃内微生物により分 解されることが知られ，分解能をもつ 2 種の細菌， $E$. Coli $T m-1$ 乙 Tm-2 が胃から単離された。両菌とも $\mathrm{pH} 6.0 \sim 7.0$ の範围で $37^{\circ} \mathrm{C}, 72 \mathrm{hr}$ の培養で $90 \%$ の分 解率を示したが，その分解物の中間体として，2-ホスホ ノアセトアルデヒドが同定されるに至った (図-8 ${ }^{33}$ 。

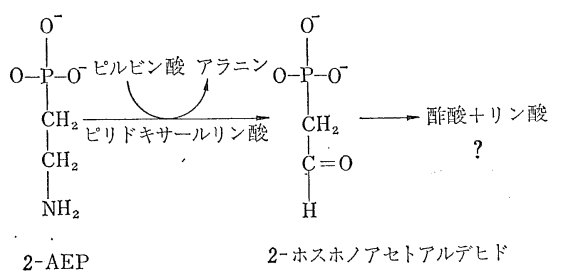

図-8 C-P 結合の開裂

\section{6 おわりに}

以上，C-P 化合物とその脂質について二，三の知見を 述べたが，興味ある問題は将来の研究に待たれるものが 多いことに読者も気付かれたことと思う。リン元素の生 体内に打汀る，従来とは異なった形態の誕生が夢多いも のとなるためにも, この方面の研究办今後, 盛んになる ことを祈りつつ管定おく次第である ${ }^{34)}$

(昭和 45 年 10 月 22 日受理)

$$
\text { 文献 }
$$

1) 宮本, 生化学, 42, 306 (1969)

2) M. Horiguchi, M. Kandatsu, Nature, 184, 901(1959)

3) G.M. Kosolapoff, J. Am. Chem. Soc., 68, 2397(1946)

4) A.F. Isebell, 7th International Congress of Biochemistry (Tokyo), Aug., Abstracts III, 447 (1967)

5）堀口，蛋白質・核酸・醅素，12，317（1967）

6) 堀, 板坂, 化学, 24, 306 (1969)

7）堀口, 生化学, 42, 401 (1970) 
8) 堀, 板坂, 化学, 23, 892 (1968)

9）野島，永井 “脂質” p. 118 朝倉書店 (1969)

10) T. Hori, O. Itasaka, H. Inoue, M. Akai, Japan J. Exp. Med., 35, 81 (1965)

11) T. Hori, M. Sugita, I. Arakawa, Biochim. Biophys. Acta. 152, 211 (1968)

12) D.C. White, A.N. Tucker, Lipids, 5, 56 (1969)

13) J.S. Kittredge, E. Roberts, Biochemistry, 1, 624(1962)

14) C.R. Liang, H. Rosenberg, Biochim. Biophys. Acta, 125, 548 (1666)

15) R.M.C. Dawson, P. Kemp, Biochem. J., 105, 837 (1967)

16) V.M. Kapoulas, Biochim. Biophys. Acta, 176, 324 (1969)

17) E. Baer, N.Z. Stanacev, J. Biol. Chem., 239, 3209 (1964)

18) J.D. Smith, Biochem. Biophys. Res. Comm., 39, 1163 (1970)

19) G. Simon, G. Rouser, Lipids, 2, 55 (1967)

20) T. Hori, I. Arakawa, M. Sugita, J. Biochem., 64, 533 (1968)

21) G. Simon, G. Rouser, Lipids, 4, 607 (1969)
22) 杉田, 板坂, 堀, 生化学, 40, 254 (1968)

23) T. Hori, O. Itasaka, M. Sugita, Mem. Shiga Univ., 17, 24 (1967)

24) A. Hayashi, T. Matsubara, Biochim. Biophys. Acta, 176, 208 (1969)

25) T. Hori, M. Sugita, J. Biochem., 65, 451 (1969)

26) T. Hori, I. Arakawa, Biochim. Biophys. Acta, 167, 989 (1969)

27）堀, 板坂, 杉田, 第 7 回国際天然物化学会議（ソ連）要 旨集 p. 292 (1970)

28）杉田, 堀, 沢田, 生化学, 40, 158 (1968)

29）堀, 杉田, 未発表

30) E. Bear, G.R. Sarma, Can. J. Biochem., 47, 603 . (1969)

31) J.S. Kittredge, R.R. Hughes, Biochemistry, 3, 991 (1964)

32) W.A. Warren, Biochim. Biophys. Acta, 156, 340 (1968)

33）玉利, 神立, 生化学, 40, 401 (1970)

34) 保田, 油化学, 18，239 (1969) 林, 松原, 松浦, 油化学, 18, 118 (1969)

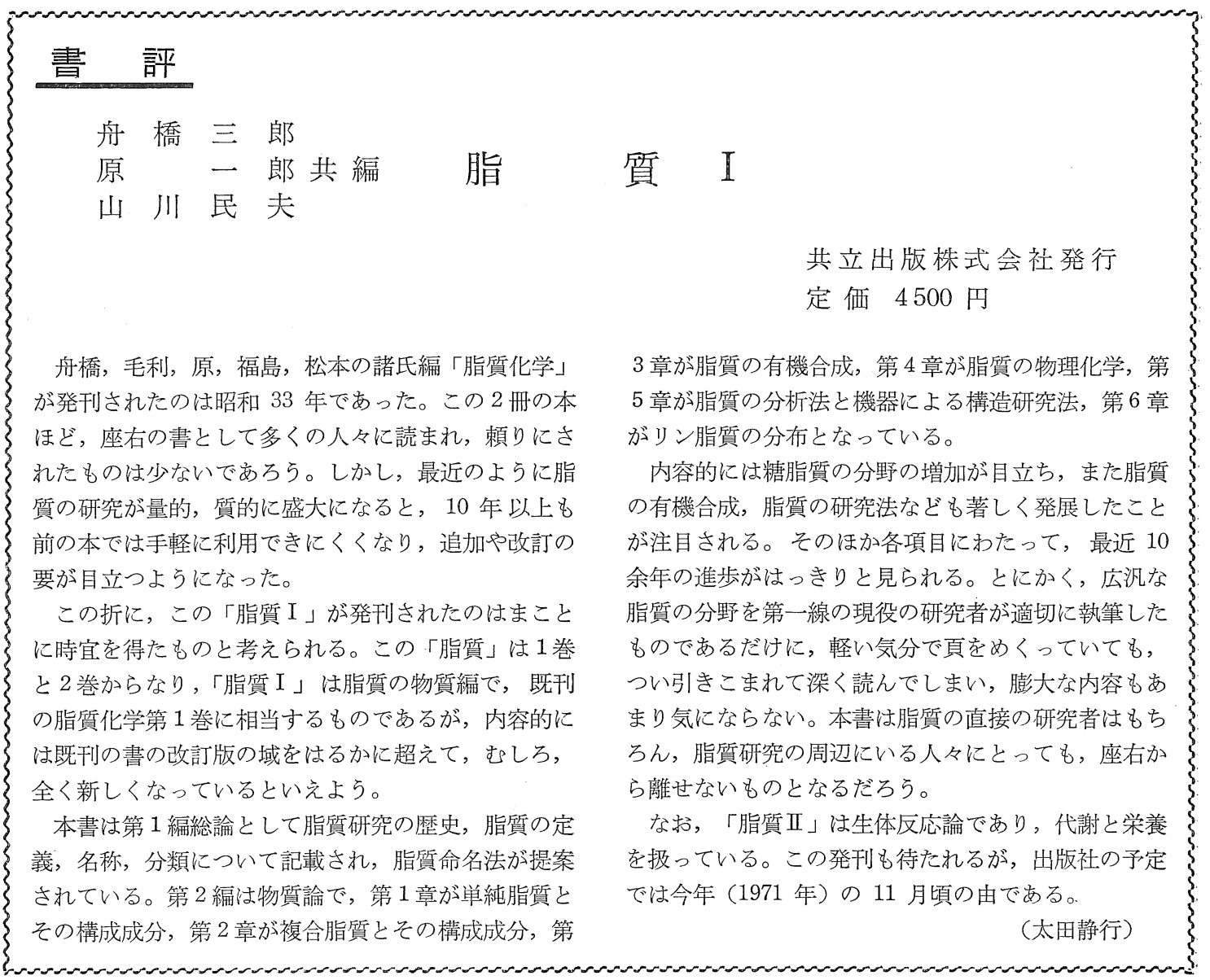

